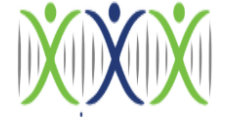

IRASD

Volume 9, Number 3, 2021, Pages 309-316

SCIENCES (PHHS

Journal Homepage:

https://journals. internationalrasd.org/index.php/pjhss

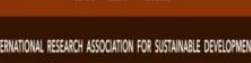

\title{
Psychological Ethical Climate in Schools and Teachers' Performance: Analyzing the Effect on Government and Private Teachers
}

\author{
Syed Zubair Haider ${ }^{1}$, Rafaquat Ali $^{2}$, Syeda Sidra Nosheen ${ }^{3}$ \\ 1 Assistant Professor, Department of Educational Training, The Islamia University of Bahawalpur, Pakistan. \\ Email: zubairiub@hotmail.com \\ 2 Assistant Professor, Department of Education, The Islamia University of Bahawalpur, Pakistan. \\ Bahawalnagar Campus. Email: rafaquatiub@yahoo.com \\ ${ }^{3}$ Assistant Professor, Department of Language Education, The Islamia University of Bahawalpur, Pakistan. \\ Email: sidra.nosheen@ymail.com
}

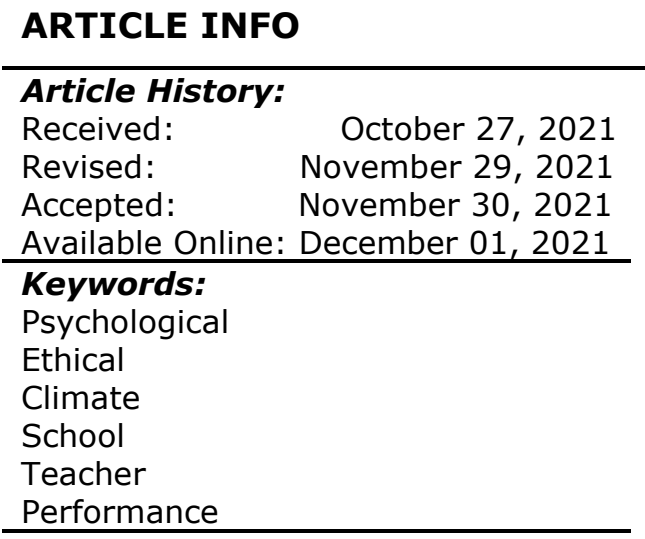

\section{ABSTRACT}

The present research examined the impact of psychological ethical climate on teachers' performance in government and private schools of Bahawalpur. In this study, the descriptive research design was used, and data were collected through two scales, such as the psychological ethical climate scale developed by Schwepker, Ferrell, and Ingram (1997) and teachers' job performance scale developed by Akhtar and Haider (2017). The simple random and convenient sampling techniques were used to select government ESEs and private school teachers and their principals to rate their performance. Total 280 questionnaires were distributed among teachers, and 60 questionnaires were provided to principals, and the response rate was $100 \%$ due to vigorous follow-up by the researchers. Researchers applied different statistical techniques to the collected data to get accurate results. This study revealed that both government and private teachers highly displayed psychological ethical climate in their schools. The study results showed that psychological ethical climate has a statistically significant effect on teachers' performance in private schools. At the same time, the effect was insignificant in government schools.

(C) 2021 The Authors, Published by iRASD. This is an Open Access Article under the Creative Common Attribution Non-Commercial 4.0

Corresponding Author's Email: rafaquatiub@yahoo.com

\section{Introduction}

Individuals' collective reflections on laws, regulations, policies, processes, and the attitudes that the organization likes respects, and favours are referred to as climate. It is a technique for businesses to operationalize day-to-day tasks and behaviours. Making an ethical work climate is one way to achieve this long-held belief that ethics should be integrated into all aspects of an organization's concerns and activities (Schwepker, 2001). Within an organization, there are a variety of climates, including community services. The most popular ones that have been examined include environment, creative atmosphere, and safety compliance climate. However, Victor and Cullen (1987) suggested a new form of climate known as Psychological Ethical Climate (PEC).

Until recently, the PEC had received very little attention as a vital and distinctive research topic. The PEC has been described as a different construct by researchers in social psychology, communication, and organizational behaviour. Throughout the previous few decades, the concept of PEC has played a significant role in administrative and educational studies. The PEC has been recognized as one of the essential variables influencing an organization's employees' ethical views. According to Cullen, Parboteeah, and Victor (2003), it is a moral perspective on the organization's regular rules and procedures that many people share. Ferrell and Gresham (1985) suggested that hostile attitudes and practices thrive in organizations where management fails to place a high value on ethics and implement ethical code of conduct, regulations, and specific directives to curb and correct unethical behaviours and attitudes. 
Chiang and Hsieh (2012) considered PEC a regulation expressing rules, policies, standards, and practices with ethical concerns of an organization's workforce. Peterson (2002) stated that positive and negative workplace attitudes, including malingering, deviant job conduct, social hanging-out, and lateness, are linked to an organization's PEC. Filipova (2011) defines organizational patterns, procedures, norms, and activities are mirrored in PEC. Shafer (2008) argued that as a critical resource and a way to guide employees through ethical dilemmas, PEC is an essential part of any school or institution. Moore and Moore (2014) define that PEC refers to the attitude considered to be morally correct and the controls and treatment of negative behaviours and the questions of poor conduct.

\section{Review of Related Literature}

The value of an ethical code of conduct could not be overlooked in increasing ethical behaviour and strengthening the PEC of an organization. It plays a vital role in the management decision-making process. McDonald (2000) argued that codes are a way for an organization to create PEC. The application of a code of ethics raises and establishes a high degree of PEC inside a school. In general, there are two techniques to analyzing PEC in an organization. The first is a cognitive strategy, and the second is a shared-perception strategy. Employees' job or workforce thinking is usually founded on neutral information or data, such as performance evaluation systems, organizational structure, incentive mechanisms and perks, employee code of behaviour, and other essential papers like official letters, orders, and memoranda. All of these documents are critical in compiling a balanced assessment of the work environment. It is thought to be a psychosomatic configuration that arose through individuals' shared reflections.

On the other hand, individuals' performance is based on their collection of attitudes related to their task. A significant relationship exists between customer satisfaction, an organization's conscious goals, and economic participation, also considered an output of the task. Armstrong (2009) found that work performance refers to an individual's success and achievement at the workplace. According to Campbell (2012), performance is defined as a person-level component in psychological perspectives. It is considered anything that is tied to a single human and something that a single individual executes. When evaluating work performance, the degree to which a person achieves or acquires a job-related quality and quantity is also considered.

People and organizations both place a high value on performance, and it is regarded as a crucial variable and pertains to accomplishing quantitative and qualitative goals. It is also defined as controlling, managing, and doing routine actions to attain goals according to predefined criteria. Ghasemi and Keshavarzi (2014) define performance as a person's attitude toward work. When it comes to the tasks, this is also regarded as an outcome or product. It is closely linked to customer (student) happiness, conscious organizational goals, and financial participation (Bernardin, Kane, Ross, Spina, \& Johnson, 1995). In most cases, it also refers to how well a person does a given work or responsibility following predetermined standards or principles.

This theory distinguishes between performance factor impacts caused by an individual's performance and those that are not. During evaluating work performance, the degree to which an individual has attained or acquired a job-related quality or quantity is also considered. Suliman and Al Kathairi (2012) expressed that if you use the word job performance, you are talking about whether or not a person completes his or her tasks appropriately. Knowledge of job obligations, willingness to innovate, and quality of work. This is a critical variable for the organization's performance and productivity, notwithstanding the disagreement over how these phenomena should be exactly described. This can also be thought of as an individual's overall output that the organization recognizes.

A plethora of studies has revealed the impact of an ethical atmosphere on individual job performance. The moral climate is regarded as one of the most critical factors influencing employee performance, promoting effectiveness, and influencing employee behaviour. Victor and Cullen (1988) concluded that employee and organizational performance are also improved by ethical behaviour and PEC. The importance of organizational ethics could not be overstated. 
They said that several studies have shown that PEC is critical to improving an organization's success. He and Cai (2012) conducted a meta-analysis of ethics in the Chinese environment found that the organizational and personal background and performance are crucial elements in the relationship between ethical difficulties and other factors.

Long and Driscoll (2008) believed that an organization's PEC could help it in improving its performance and productivity. The PEC is thought to have a good effect on performance as a result of this prevalent belief. Many studies have looked at the link between PEC and work performance and organizational performance (Hosmer, 1994). Riivari, Lämsä, Kujala, and Heiskanen (2012) explored that in terms of organizational process innovation and strategy, PEC and culture have a positive link. The organization's innovativeness is also seen as a system that demonstrates how PEC impacts organizational performance. Koo Moon and Kwon Choi (2014) argued that employees and organizations could benefit from having a high PEC. Furthermore, the organization with PEC function better by increasing their inspiration and desire to revolutionize.

Jaramillo, Mulki, and Solomon (2006) concluded that a suitable PEC promotes occupational performance by implementing a system of attitude and pressure. School PEC and teacher performance have been linked in numerous researches. Selamat, Samsu, and Kamalu (2013) conducted a study to see how climate affects teachers' job performance. They discovered a strong link between organizational PEC and school teachers' job satisfaction and quality of work. On the other hand, a healthy organizational PEC has a considerable beneficial effect on teachers' performance and improves it. It is strongly recommended that PEC and teacher performance be studied in various situations and cultures. Several pieces of research have been conducted in advanced countries. However, comparatively little research was undertaken in Punjab to identify this significant problem. Therefore, this study tries to address this gap by examining PEC's impact on teachers' performance in Bahawalpur. This study has defined different objectives. The study aimed at measuring;

(a) The level of PEC of government and private schools as perceived by their teachers,

(b) The mean difference among demographic variables regarding PEC,

(c) The effect of PEC on government and private teachers' performance

\section{Materials and Methods}

The present research analyzes the impact of PEC of the institution on teachers' performance. The survey research design of a descriptive study was used for data collection. According to Haider and Hussain (2014), descriptive research is appropriate for analyzing any current scenario. It is a data collection approach to test a hypothesis or respond to research inquiries regarding the current and previous state of the research (Haider \& Qureshi, 2016). Questionnaires and interviews are the essential tools of data collection. However, in this present research, data were collected through a questionnaire.

\subsection{Sample and Sampling}

The study population consisted of Elementary School Educator (ESEs) working in government schools and private teachers teaching the primary level classes in private schools of district Bahawalpur. Total 60 schools (30 government $(50 \%)$ and 30 private $(50 \%)$ ) were selected through a convenient sampling technique. Out of 30 government schools, 15 (50\%) were boys' schools, and $15(50 \%)$ were girls' schools. From each government school, 04 teachers were randomly selected. So, $60(50 \%)$ male teachers and $60(50 \%)$ female teachers were selected from government schools through simple random sampling using the lottery method. Similarly, from 30 private schools, 04 teachers (01 male and 03 female, because in private schools, the number of female teachers is higher than male teachers) were randomly selected.

So, $30(25 \%)$ male teachers and $90(75 \%)$ female teachers were selected from private schools through simple random sampling by using the lottery method. The mean age for government male teachers $=31.69$ years, and for female government teachers $=27.15$ years. Almost the mean age for private male teachers $=28.36$ years, and for private female teachers $=24.52$ years. For measuring teachers' performance, 60 principals ( 30 government ( 15 male and 15 female) and 30 private ( 20 male and 10 female) from already selected schools were also requested to rate their teachers' performance by using a specifically designed teachers' 
performance scale. So out of 60 principals, 35 (58.33\%) were male, and $25(41.66 \%)$ were female principals. The mean age for male principals $=38.12$ years, and for female principals $=$ 36.71 years.

\subsection{Research Tool}

\subsubsection{Psychological Ethical Climate Scale (PECS)}

PECS developed by Schwepker, Ferrell, and Ingram (1997) was considered most appropriate in this study context. With the author's permission, the scale was changed and modified. In the adapted version, the phrases corporation and sales executive were replaced with school and teacher, respectively, while item \# 7 was removed owing to non-compliance with study criteria. The reliability coefficient for government teachers $a=0.89$, and for private teachers were $a=0.86$ respectively. The overall Cronbach's alpha of PECS for this study was 0.90 .

\subsubsection{Teachers' Job Performance Scale (TJPS)}

A TJPS developed by Akhtar and Haider (2017) for measuring teachers' performance was considered most appropriate in this study context and used after getting authors' permission. Principals usually use this scale to rate their teachers' performance based on their perceptions. This scale has consisted of 24 items based on 3 subscales (08 items each) such as instructional qualities (government $a=0.85$, private $a=0.82$ ), professional qualities (government $a=0.88$, private $a=0.85$ ), and personal qualities (government $a=0.91$, private $a=0.90$ ) respectively. The overall Cronbach's alpha of TJPS for this study was 0.86 .

\section{Results}

In the current study, the main focus was on PEC and its impact on teachers' performance in government and private schools. The data analysis process takes place in two steps. Initially, SPSS 22nd version was used to conduct Exploratory Factor Analysis (EFA). In the second phase, mean, SD, t-test, correlation, and regression were performed.

Table 1: Factor Structure for Government and Private Teachers regarding PEC

\begin{tabular}{cccc}
\hline \multirow{2}{*}{ Factors } & \multirow{2}{*}{ Items } & \multicolumn{2}{c}{ Factor Loadings } \\
\cline { 3 - 4 } & & Government & Private \\
\hline Psychological Ethical Climate & Item 1 & .831 & .811 \\
& Item 2 & .810 & .768 \\
& Item 3 & .784 & .719 \\
& Item 4 & .733 & .639 \\
& Item 5 & .612 & .618 \\
& Item 6 & .539 & .483 \\
\hline
\end{tabular}

One factor was extracted from the EFA of 06-items using the principal component method and varimax rotation with its eigenvalue greater than 2 and brought a reasonable more than $61.23 \%$ of the common variance for government $57.61 \%$ for private teachers. The EFA suggests that this result is consistent with the actual scale's theoretical suggestions.

Table 2: Mean and SD regarding Teachers' Perspectives on PEC

\begin{tabular}{|c|c|c|c|c|}
\hline \multirow[t]{2}{*}{ Items } & \multicolumn{2}{|c|}{$\begin{array}{l}\text { Governmen } \\
\text { t ESEs }\end{array}$} & \multicolumn{2}{|c|}{$\begin{array}{l}\text { Private } \\
\text { Teacher }\end{array}$} \\
\hline & Mean & SD & Mean & SD \\
\hline A documented code of ethics exists at my school & 3.10 & 0.69 & 3.30 & 0.56 \\
\hline A code of ethics is enforced at my school & 3.19 & 0.80 & 3.00 & 0.61 \\
\hline $\begin{array}{l}\text { My school has regulations in place that govern ethical } \\
\text { behavior }\end{array}$ & 3.11 & 0.54 & 3.16 & 0.71 \\
\hline $\begin{array}{l}\text { My school's regulations on ethical behavior are carefully } \\
\text { enforced }\end{array}$ & 3.21 & 0.82 & 3.01 & 0.79 \\
\hline $\begin{array}{l}\text { There is zero tolerance for unethical behavior in my } \\
\text { school }\end{array}$ & 3.17 & 0.68 & 2.99 & 0.76 \\
\hline $\begin{array}{l}\text { If a teacher engages in unethical behavior at my school, } \\
\text { he or she is immediately warned. }\end{array}$ & 3.20 & 0.59 & 2.97 & 0.71 \\
\hline Average & 3.21 & 0.62 & 3.10 & 0.61 \\
\hline
\end{tabular}


Table 2 reveals the mean and SD of each statement on PEC. The average score for government $(M=3.21, S D=0.62)$ and private $(M=3.10, S D=0.61)$ teachers revealed that teachers in both government and private schools agree on the amount of PEC in their schools. In government ESEs, the most common response was "school's regulations on ethical behavior are carefully enforced" $(M=3.21, S D=0.82)$ and in private teachers "school has regulations in place that govern ethical behavior" $(M=3.16, S D=0.71)$. Generally, government ESEs are happier and more satisfied on the PEC level in their schools than private teachers.

Table 3: The Comparison of Teachers' Demographics regarding PEC

\begin{tabular}{ccccccccc}
\hline \multirow{2}{*}{ Category } & \multicolumn{3}{c}{ Government ESEs } & \multicolumn{5}{c}{ Private Teachers } \\
\cline { 2 - 9 } & Mean & SD & t & Sig & Mean & SD & t & Sig \\
\hline Male & 3.09 & 0.49 & .961 & .311 & 2.89 & 0.62 & 3.619 & .001 \\
Female & 3.13 & 0.61 & & & 3.20 & 0.68 & & \\
Urban & 3.23 & 0.51 & 1.309 & .483 & 3.24 & 0.63 & 4.127 & .031 \\
Rural & 3.20 & 0.60 & & & 3.05 & 0.61 & & \\
Public & 3.21 & 0.62 & 2.628 & .024 & & & & \\
Private & 3.10 & 0.61 & & & & & & \\
\hline
\end{tabular}

The mean, SD, independent sample t-test were performed regarding teachers' demographics and PEC (Table 3). In gender wise comparison, the difference is insignificant between male $(M=3.09, S D=0.49)$ and female $(M=3.13, S D=0.61)$ government ESES regarding PEC, $\mathrm{t}(119)=.961, \mathrm{p}=$ n.s. Conversely, there is a significant difference between male $(M=2.89, S D=0.62)$ and female $(M=3.20, S D=0.68)$ private school teachers regarding PEC, $\mathrm{t}(119)=3.619, \mathrm{p}<.001$. Moreover, the high average value of female teachers in both government and private schools showed that they are more agreed and happier with the prevalence of PEC in their schools then male teachers.

Furthermore, location wise analysis also depicts insignificant difference between urban $(M=3.23, S D=0.51)$ and rural $(M=3.20, S D=0.60)$ government ESEs regarding PEC, $\mathrm{t}(119)=1.309, \mathrm{p}=$ n.s. Conversely, there is a significant difference between urban $(\mathrm{M}=$ $3.24, \mathrm{SD}=0.63)$ and rural $(\mathrm{M}=3.05, \mathrm{SD}=0.61)$ private school teachers regarding $\mathrm{PEC}$, $\mathrm{t}(119)=4.127, \mathrm{p}<.031$. Moreover, the high average value of urban schools' teachers in both government and private sector showed that they are more agreed and happier with the prevalence of PEC in their schools then rural schools.

Besides, the school type wise comparison presents a significant difference between government $(M=3.21, S D=0.62)$ and private $(M=3.10, S D=0.61)$ teachers regarding PEC, $\mathrm{t}(239)=2.628, \mathrm{p}<.024$. Overall, the high average value of government ESEs demonstrated that they are more agreed and happier regarding PEC in their schools then private teachers.

Table 4: Teachers' Academic and Professional Qualification Effect on PEC

\begin{tabular}{cccccccccc}
\hline \multirow{2}{*}{ ANOVA } & & \multicolumn{4}{c}{ Government ESEs } & \multicolumn{4}{c}{ Private Teachers } \\
\cline { 2 - 10 } & & SS & MS & F & Sig & SS & MS & F & Sig \\
\hline Acad Qualification & BG & 3.59 & 0.63 & 3.214 & .071 & 2.78 & .53 & 2.018 & .329 \\
& WG & 164.29 & .34 & & & 133.89 & .29 & & \\
Prof Qualification & BG & 0.62 & .21 & .401 & .386 & 2.31 & .60 & 2.007 & .211 \\
& WG & 149.71 & .30 & & & 119.81 & .28 & & \\
\hline
\end{tabular}

Note: $\mathrm{SS}=$ Sum of Squares, MS = Mean Square, BG = Between Group, WG = Within Group

Analysis of Variance was performed on academic and professional qualification of teachers (Table 4). The main effect of academic qualification of government $\operatorname{ESEs,~} F(4,116)=$ $3.214, p=n . s$, and private teachers, $F(4,116)=2.018, p=n . s$, was insignificant regarding PEC. Likewise, the main effect of professional qualification of government ESEs, $F(4,116)=$ $.401, \mathrm{p}=\mathrm{n} . \mathrm{s}$, and private teachers, $\mathrm{F}(4,116)=2.007, \mathrm{p}=\mathrm{n} . \mathrm{s}$, was also insignificant regarding PEC in schools.

The impact of PEC on teachers' performance was described in Table 5 . There is insignificant contribution of PEC $\left(R^{2}=.011, F(1,119)=2.117, p=n . s\right)$ on government teachers' performance. The findings depict that teachers' performance is not dependent on 313 
PEC in government schools. Conversely, there is a significant contribution and $10.6 \%$ variance is explained by PEC $\left(R^{2}=.106, F(1,119)=4.311, p<.05\right)$ on private teachers' performance based on principals' observation. Furthermore, the findings expressed that one unit increase in the PEC will bring $15.1 \%$ increase $(\beta=.151, p<.05)$ in teachers' performance in private schools. On the other hand, government and private mix data revealed insignificant effect of $\operatorname{PEC}\left(R^{2}=.014, F(1,119)=1.651, p=n . s\right)$ on teachers' performance.

Table 5: The impact of PEC on Teachers' Performance (Regression Analysis)

\begin{tabular}{cccccc}
\hline & Dependent Variable & $\boldsymbol{\beta}$ & $\mathbf{t}$ & $\mathbf{F}$ & $\mathbf{R}^{\mathbf{2}}$ \\
\hline Government & Teachers' Performance & .043 & 1.817 & 2.117 & .011 \\
Private & Teachers' Performance & .151 & $3.151^{*}$ & $4.311^{*}$ & .106 \\
Government*Private & Teachers' Performance & .201 & 1.651 & 3.224 & .014 \\
\hline
\end{tabular}

$* p<.05$,

\section{Conclusion and Policy Implications}

The educational environment in Pakistan makes it easy to understand how the teacher has numerous obstacles in carrying out his sacred duties as the essential factor of educational transformation. Many variables influence teachers' performance; yet, issues relating to school have a direct or implicit influence on school performance. The current study examined the impact of PEC on government and private teachers' performance in Bahawalpur. It was difficult to quantify the ideas discussed in this study. However, after an adequate modification, an attempt has been made to determine its links using the best instruments available.

According to study findings, private teachers and ESEs in government schools appeared to be happy about the level of PEC in their schools. They believed that their schools strictly enforced and upheld the code of ethics. The findings also show no statistically significant difference between male and female ESEs regarding PEC in government schools. However, there is a considerable disparity between male and female private school teachers relating to PEC in their institutions. Furthermore, female teachers in public and private schools had a higher average value, indicating that they were more satisfied and agreed with the PEC level than male instructors. Similarly, PEC did not change significantly between urban and rural ESEs of government schools.

In contrast, the PEC is drastically different for instructors in both urban and rural private schools. The high average value of government and private school urban teachers has demonstrated that urban teachers are more satisfied and agree that PEC levels dominate their then rural schools. Furthermore, in their schools, there is a significant discrepancy in PEC between government and private teachers. The findings showed that Government instructors are more satisfied and satisfied with the PEC level than private teachers. The results showed that the academic qualification and the perception of PEC were insignificant in both the government and private teachers. Furthermore, both government and private teachers had no significant impact on PEC as regards professional qualifications. The PEC was not significantly different for teachers without qualifications, B.Ed, M.Ed, and M.A Education.

The studies also suggested that the PEC of schools has little effect on teachers' performance in government ESEs. While PEC of their schools has a weak significant impact on teachers' performance in private schools, it has a significant weak effect on teachers' performance in public schools. The outcomes are also in line with Weeks and Nantel (1992) found a substantial impact on employee performance of the ethical climate of the institution. Peterson (2002) described that the ethical climate is intimately tied to its teachers' good behaviors and excellent job performance. The findings of this study are consistent with those of other studies that have discovered that an ethical climate can support and impact the work performance of individuals inside an organization (Victor \& Cullen, 1988), and institutional profitability is influenced by the ethical climate of the school as well as teachers' ethical behavior (Christie, Kwon, Stoeberl, \& Baumhart, 2003). PEC, on the other hand, has no discernible effect on teachers' performance in this study. 
On the contrary, Pritchard and Karasick (1973) argued that the ethical context had been shown to influence various outcomes, including individual work performance. Long and Driscoll (2008) found that organizational and employee performance can benefit from an ethical climate. The findings of this study corroborate those of several other studies conducted in industrialized countries, except for a few rare exceptions that did not produce similar results.

\section{References}

Ali, A., \& Haider, S. Z. (2017). Developing a Validated Instrument to Measure Teachers' Job Performance: Analyzing the Role of Background Variables. Journal of Educational Research, 20(1), 21-35.

Armstrong, M. (2009). Armstrong's handbook of performance management: An evidencebased guide to delivering high performance (4th ed.). London: Kogan Page Limited.

Bernardin, H. J., Kane, J. S., Ross, S., Spina, J., \& Johnson, D. (1995). Performance Appraisal Design, Development and Implementation (Vol. 462). Cambridge: M.A.

Campbell, J. P. (2012). Behavior, performance, and effectiveness in the twenty-first century. In S. W. J. Kozlowski (Ed.), The Oxford handbook of organizational psychology, Vol. 1, pp. 159-194. Oxford University Press.

Chiang, C.-F., \& Hsieh, T.-S. (2012). The impacts of perceived organizational support and psychological empowerment on job performance: The mediating effects of organizational citizenship behavior. International Journal of Hospitality Management, 31(1), 180-190. doi: https://doi.org/10.1016/j.ijhm.2011.04.011

Christie, P. M. J., Kwon, I.-W. G., Stoeberl, P. A., \& Baumhart, R. (2003). A cross-cultural comparison of ethical attitudes of business managers: India Korea and the United States. Journal of Business Ethics, 46(3), 263-287. doi: https://doi.org/10.1023/A: 1025501426590

Cullen, J. B., Parboteeah, K. P., \& Victor, B. (2003). The effects of ethical climates on organizational commitment: A two-study analysis. Journal of Business Ethics, 46(2), 127-141. doi: https://doi.org/10.1023/A:1025089819456

Ferrell, O. C., \& Gresham, L. G. (1985). A contingency framework for understanding ethical decision making in marketing. The Journal of Marketing, 49(3), 87-96. doi: https://doi.org/10.1177/002224298504900308

Filipova, A. A. (2011). Relationships among ethical climates, perceived organizational support, and intent-to-leave for licensed nurses in skilled nursing facilities. Journal of Applied Gerontology, 30(1), 44-66. doi: https://doi.org/10.1177/0733464809356546

Ghasemi, B., \& Keshavarzi, R. (2014). The relationship between organizational climate, organizational commitment and organizational citizenship behavior in a hospital environment. Reef Resources Assessment and Management Technical Paper, 40(2), 759-773.

Haider, S. Z., \& Hussain, A. (2014). Relationship between teacher factors and student achievement: A correlational study of secondary schools. US-China Education Review A, $4(7), 465-480$.

Haider, S. Z., \& Qureshi, A. (2016). Are All Children Equal? Causative Factors of Child Labour in Selected Districts of South Punjab, Pakistan. Journal of New Approaches in Educational Research, 5(1), 3-10.

Hosmer, L. T. (1994). Strategic planning as if ethics mattered. Strategic Management Journal, 15(2), 17-34. doi: https://doi.org/10.1002/smj.4250151003

Jaramillo, F., Mulki, J. P., \& Solomon, P. (2006). The role of ethical climate on salesperson's role stress, job attitudes, turnover intention, and job performance. Journal of Personal Selling \& Sales Management, 26(3), 271-282. doi: https://doi.org/10.2753/PSS08853134260302

Koo Moon, H., \& Kwon Choi, B. (2014). How an organization's ethical climate contributes to customer satisfaction and financial performance: Perceived organizational innovation perspective. European Journal of Innovation Management, 17(1), 85-106. doi: https://doi.org/10.1108/EJIM-03-2013-0020

Long, B. S., \& Driscoll, C. (2008). Codes of ethics and the pursuit of organizational legitimacy: Theoretical and empirical contributions. Journal of Business Ethics, 77(2), 173-189. doi: https://doi.org/10.1007/s10551-006-9307-y

McDonald, G. (2000). Business ethics: Practical proposals for organizations. Journal of Business Ethics, 25(2), 169-184. doi: https://doi.org/10.1023/A:1005939232327 
Moore, H., \& Moore, T. (2014). The effect of ethical climate on the organizational commitment of faculty members. Journal of Academic and Business Ethics, 9(2), 1-15.

Peterson, D. K. (2002). Deviant workplace behavior and the organization's ethical climate. Journal of Business and Psychology, 17(1), 47-61. doi: https://doi.org/10.1023/A:1016296116093

Pritchard, R. D., \& Karasick, B. W. (1973). The effects of organizational climate on managerial job performance and job satisfaction. Organizational behavior and human performance, 9(1), 126-146. doi: https://doi.org/10.1016/0030-5073(73)90042-1

Riivari, E., Lämsä, A.-M., Kujala, J., \& Heiskanen, E. (2012). The ethical culture of organisations and organisational innovativeness. European Journal of Innovation Management, 15(3), 310-331. doi: https://doi.org/10.1108/14601061211243657

Schwepker, C. H., Ferrell, O., \& Ingram, T. N. (1997). The influence of ethical climate and ethical conflict on role stress in the sales force. Journal of the Academy of Marketing Science, 25(2), 99-108. doi: https://doi.org/10.1007/BF02894345

Schwepker, C. H. (2001). Ethical climate's relationship to job satisfaction, organizational commitment, and turnover intention in the salesforce. Journal of Business Research, 54(1), 39-52. doi: https://doi.org/10.1016/S0148-2963(00)00125-9

Selamat, N., Samsu, N. Z., \& Kamalu, N. S. M. (2013). The Impact of Organizational Climate on Teachers' Job Performance. Educational Research, 2(1), 71-82. doi: http://dx.doi.org/10.5838/erej.2013.21.06

Shafer, W. E. (2008). Ethical climate in Chinese CPA firms. Accounting, Organizations and Society, 33(7), 825-835. doi: https://doi.org/10.1016/j.aos.2007.08.002

Suliman, A., \& Al Kathairi, M. (2012). Organizational justice, commitment and performance in developing countries: The case of the UAE. Employee Relations, 35(1), 98-115. doi: https://doi.org/10.1108/01425451311279438

Victor, B., \& Cullen, J. B. (1987). A theory and measure of ethical climate in organizations. Research in Corporate Social Performance and Policy, 9(1), 51-71.

Victor, B., \& Cullen, J. B. (1988). The organizational bases of ethical work climates. Administrative Science Quarterly, 33(1), 101-125. doi: https://doi.org/10.2307/2392857

Weeks, W. A., \& Nantel, J. (1992). Corporate codes of ethics and sales force behavior: A case study. Journal of Business Ethics, 11(10), 753-760. doi: https://doi.org/10.1007/BF00872307

He, Y., \& Cai, T. (2012). The ethics of employment relations in China: a meta-analysis. Chinese Management Studies, 6(2), 341-349. doi: https://doi.org/10.1108/17506141211236767 